\title{
The 'Thing' Called 'Mineral Right' Re-examining the nature, content and scope of a rather confounding concept in South African law
}

\author{
Hanri Mostert*
}

\section{Summary}

The nature of a right to minerals is controversial in South Africa. With the recent coming into force of new legislation governing mineral resources, the conventional view is that there has been a drastic shift of control over the country's mineral wealth from private individuals to the state. However, in this article, the author explains that the conceptualisation of the mineral right in South Africa has always been inconsistent and contested, at least partly due to South Africa being a mixed legal system with conflicting theoretical foundations. With reference to Underkuffler's theoretical framework of the legitimate regulatory powers of the state over property, the author demonstrates that the orthodox view in South Africa has historically emphasised the powers of private parties over mineral resources and viewed the state's legitimate regulatory role as limited. However, the author argues, both historically and conceptually it is more accurate to acknowledge that the state has always exercised significant control over mining in South Africa, and the right to minerals has always been a flexible one which has varied across different legislative periods. The article outlines the evolution of the mineral right in South Africa, discusses the conflicting theoretical conceptions of the right (including whether it is servitudal in nature or an independent property right) and critiques the recent judicial treatment of the right by South Africa's highest courts. The author concludes by suggesting that if the mineral right is understood correctly, the recent legislative changes are actually far less radical than commonly thought.

* BA LLB LLM LLD (Stell); Professor of Law, University of Cape Town and Visiting Professor, Centre for Law and Governance and Department for Private and Notary Law, Rijksuniversiteit Groningen. I hope I have done justice to the valuable comments provided on earlier drafts of this essay by my colleagues in the Department of Private Law at UCT, the Progressive Property Law group's gathering in Boston, in 2014, Prof Pieter Badenhorst and the Masterclass participants of the Young Property Lawyers' Forum of 2012. Richard Cramer, Iain Shipley and Janine Howard rendered much appreciated research assistance. The financial support of the National Research Foundation and the Africa Knowledge Project of the Programme for the Enhancement of Research Capacity at the University of Cape Town is gratefully acknowledged. Opinion and remaining errors are my own and should not be attributed to these institutions. 


\section{Introduction}

In 1866, the Cape Colony at the southern-most tip of Africa was one of the most backward outposts of the British Empire. ${ }^{1}$ For the colonial authorities, having the territory was not worth the constant hassles with either the indigenous peoples ${ }^{2}$ or the rather demanding settlers, ${ }^{3}$ not to mention their obstinate neighbours in the Boer republics. ${ }^{4}$ If the colonial administration could, they probably would have rid the British Empire of the Cape Colony. ${ }^{5}$

Such was the political climate on that otherwise fine day when the farmer Schalk van Niekerk visited a neighbour and noticed the boy Erasmus Jacobs playing with an interesting looking 'glittering' white pebble that he picked up on the banks of the Orange River. ${ }^{6}$ The rest is history: the pebble turned out to be the Eureka diamond. ${ }^{7}$ When the even more spectacular Star of South Africa was found soon afterwards, and gold was discovered on the Witwatersrand not much later, it changed the destiny of this country at the southern tip of

1 M Meredith, Diamonds, gold and war: The making of South Africa, Jeppestown, (2007/2008), 3.

2 The alluvial diggings for diamonds at Pniel, in the Cape, were claimed by both Nicholas Waterboer of Griquatown the Thaping chief Mahura, the South African Republic, the Orange Free State (see note 3 below) and the diggers who had set up their own republic. The Dry Diggings at Du Toit's Pan were also the subject of dispute as surveyors disagreed on whether they fell to the east or west of the boundary separating the lands of Kok from those of the Waterboer. The Griqualand rebellian was in part due to many land claims being refused by the Griqualand West Land Court. The rebellion was ended by Colonel Charles Warren reopening the land question and making provision for many Griqua claims to be confirmed. See TRH Davenport and C Saunders, South Africa: A modern history, 5 ed, London, (2000) 152-155.

3 White settlers were accostomed to managing their own affairs through diggers' associations and violence, if necessary. Above all else the diggers had tried to limit the activities of blacks in the diamond fields and reduce their ability to compete with white diggers for work. This culminated in 1872 when Kimberly's white residents demanded that new laws be enacted to control black workers. They also demanded that blacks and coloureds not be allowed to hold digging licenses. Violent protests began and the British officials were unable to adequately restore order. Faced with increasing demands and threats of violence, the British Officials gave in to most of the diggers' demands and the Proclamation 14 of August 1872 set the scene for a new regime of labour contracts; See $M$ Meredith, n 1, 41-47.

4 The Orange Free State disputed whether the alluvial diggings at Pniel and the Dry Diggings at Du Toit's Pan (see note 2 above) fell within its territory. President Johannes Brand went as far as appointing a landdrost to preside at Pniel. A school, a courthouse and a prison were built there. The Free State Volksraad proceeded to pass legislation regulating the activities of diggers. Following the opening of the dry diggings, the appointed landdrost sought to 'supervise the diggers' committees and collect a portion of license fees'. Although the river diggings were unquestionably outside the boundaries of the South African Republic, President Marthinus Wessels Pretorius sent mounted police and a magristrate to the north bank of the Vaal River, claiming rights there as well. M Meredith, $\mathrm{n} 1,23$.

5 M Meredith, $\mathrm{n} 1,3$.

6 Anonymous, Hopetown, available at http://www.heritage.org.za/karoo/hope.htm, accessed on 14 January 2012, 16.

7 M Meredith, n 1, 16. 
Africa, shifting the society rather rapidly from one based largely on agriculture to one of industries, primarily reliant on the extraction of minerals. ${ }^{8}$

\section{A. Background to the analysis}

Founded on agriculture, as early colonial South Africa was, ${ }^{9}$ its property laws operated largely in favour of landowners when its mineral wealth was first discovered: the property law tradition imported as part of the settlement of the Dutch at the Cape supported the cuius est solum ${ }^{10}$ rule, affording the landowner the right to the surface and to what lies beneath it. It did so, according to the most prevalent views, in 'all the fullness that the common law allow[ed]'. ${ }^{11}$ Landowners valued the great deal of liberty and autonomy they enjoyed. In fact, one of the catalysts of the Great Trek ${ }^{12}$ was a Proclamation of $1813,{ }^{13}$ attributed to Sir John Cradock, ${ }^{14}$ which significantly altered Roman-Dutch law pertaining to land in important ways. It was this Proclamation's introduction of the quitrent system that the Boers found objectionable. ${ }^{15}$ They regarded the regulatory and taxation provisions as unduly interfering with their liberty and autonomy, and ultimately also their property rights. ${ }^{16}$

8 In 1913, agriculture contributed $£ 60,000,000$ to the GDP, while mining contributed $£ 87,000,000$. See CH Feinstein, An Economic History of South Africa: Conquest, Discrimination and Development, Cambridge, (2005) 115.

9 CH Feinstein, $\mathrm{n} 8,2$.

10 Cuius est solum eius est usque ad caelum et ad inferos ('the owner of the land is the owner of the sky above and everthing contained in the soil below the surface'). See PJ Badenhorst, JM Pienaar and H Mostert, Silberberg and Schoeman's the Law of Property, 5 ed, Butterworths, (2006) $92 \mathrm{n}$ 11; Trojan Exploration Co (Pty) Ltd and Another v Rustenburg Platinum Mines Ltd and Others 1996 (4) SA 499 (A) 537C; see PJ Badenhorst, E Van der Vyfer and C Van Heerden, Proposed nationalisation of mineral rights in South Africa, Journal of Energy and Natural Resources Law 12 (1994) 287 495, 502. See also H Mostert, Mineral Law: Principles and policies in perspective, Cape Town, (2012) 7-8.

11 Trojan Exploration Co (Pty) Ltd and Another v Rustenburg Platinum Mines Ltd and Others 1996 (4) SA 499 (A) at 509B.

12 I.e. that exodus of the mainly Dutch-speaking colonists, known as the 'Boers', away from British rule, in search of a place where they could establish their own independent state. More detail in TRH Davenport and C Saunders, n 2, 51-54; H Giliomee, The Afrikaners: Biography of a people, Cape Town, (2003) 145.

13 Proclamation on Conversion of Loan Places to Quitrent Tenure, 1813 (6.8.1813).

14 Elphick and H Giliomee, The shaping of South African society, 1652-1840, 2 ed, Cape Town, (1989) 332.

15 H Giliomee, n $12,145$.

16 As a result of the quitrent Cradock proclamation, all loan farms were rescinded and properly mapped. They were reallocated to the previous occupants in the form of perpetual quitrent, with certain reservations in favour of the state. The annual rent was 250 Rix-Dollars, which was much higher than the earlier loan farm system. See CG Van der Merwe, Sakereg, 2 ed, Durban, (1989) 585-586. 
The Cradock Proclamation did not intend to influence the ownership of private mineral rights, but nevertheless 'created a Gordian knot, ${ }^{17}$ because by reserving the 'right to mine' precious stones, gold and silver for the Government, it made an important statement about the relationship between the state's sovereignty over resources, and the possibility of the vesting private ownership in respect of such resources. According to principles attributed to property law in the common law context, property was generally regarded ${ }^{18}$ as absolute, in the sense that 'real rights were taken to provide absolute certainty as to the control over property and the ability to protect this control. ${ }^{\prime 19}$ Flowing from this, there was the assumption that owners were able to exclude others from the use and enjoyment of their property. Authoritative scholarly analyses have since shown, however, that absoluteness as a core principle of property law has always been somewhat contentious, ${ }^{20}$ and that the exclusivity characteristic attributed to ownership has always been severely diluted. Nevertheless, in the formative years of South African mineral law, assumptions in respect of absoluteness and exclusivity had not yet been subjected to strict scrutiny.

In 1813, when the rights to crown minerals were reserved, there was no telling how important this intervention would turn out to be. Mineral resources would become a key component of the South African economy and society only half a century later. But once the scope of South Africa's mineral wealth had become apparent, the inherent identity crisis of the right to minerals, underscored by the Cradock Proclamation, became a persistent feature accompanying the development of mineral law in South Africa. ${ }^{21}$

\section{B. Motivation for inquiry}

In this paper, I propose that mineral rights were erroneously conceptualised in law from their very commencement. It is my opinion - one which I hope to motivate in the analysis that follows - that the incorrect understanding of the concept and structure of mineral rights continues to muddy interpretations of current mineral law. The irony is that current South

17 FT Cawood and RCA Minnitt, A historical perspective on the economics of the ownership of mineral rights ownership, Journal of the South African Institute of Mining and Metallurgy (1998) 369, 370 .

18 CG Van der Merwe, n 16, 12-13; J Scholtens, Law of Property, in H R Hahlo and E Kahn (eds), The Union of South Africa, London, (1960) 578-579.

19 H Mostert and A Pope, The Principles of the Law of Property in South Africa, Cape Town, (2010) 345.

20 D Visser, The absoluteness of ownership: The South African Common Law in perspective, Acta Juridica (1985) 39 and $P$ Birks, The Roman Law concept of dominium and the idea of absolute ownership, Acta Juridica (1985) 1 indicated convincingly that the absoluteness of ownership is based on a misunderstanding of the civilian principles that underpin South African property law. More recently, see also $H$ Scott, Absolute ownership and legal pluralism in Roman Law: Two arguments, Acta Juridica (2011) 23.

21 J Milton, Ownership, in Reinhard Zimmermann and Danie P Visser (eds), Southern Cross: Civil Law and Common Law in South Africa, Cape Town, (1996) 680-682. 
African law no longer acknowledges the concept of private mineral rights. ${ }^{22}$ Conceptually, the term 'mineral right' is dead. The introduction of the Mineral and Petroleum Resource Development Act (the MPRDA), ${ }^{23}$ phased out the term 'mineral right', and replaced it with other terms such as 'mining right' and 'prospecting right'. ${ }^{24}$ Collectively, the rights options envisaged by the MPRDA are frequently, and somewhat artificially, referred to as 'rights to minerals' in scholarship, to distinguish them from the common law concept of 'mineral rights'. Yet, even though the latter concept in principle no longer exists, it still seems to influence modern understandings of mineral law. It rules from the grave, so to speak. It is my argument here that perpetuating an understanding embedded in the concept of a privatelaw mineral right is erroneous in terms of the current statutory regime dealing with minerals, and it was dubious in previous regimes that relied on the private-law organisation of mineral law in any case.

The cue for this analysis is taken from the litigation in the matter between Agri South Africa and the Minister of Minerals and Energy. ${ }^{25}$ The matter involved the legitimacy of the transitional provisions of the MPRDA. ${ }^{26}$ The case involved a dispute between the relevant Ministry and a lobby organisation for commercial farming interests. The latter's argument was that by coming into force, the MPRDA brought about a direct expropriation of certain interests that existed previously. These interests pertained to mineral rights that were not actively exercised before the MPRDA became operative. These 'unused' rights would expire within one year after the MPRDA came into force, unless they were converted under the MPRDA, which is built on a use-it-or-lose-it policy for mineral and petroleum resources. It thus provides only for rights that are actively used. The dispute attacked the core provisions of the MPRDA, those creating the model of state custodianship, as amounting to an unconstitutional expropriation of property. The case thus challenged the conflicted property law matrix of South African mineral law. A challenge of this nature had the potential of ruining attempts at transforming the mining industry and redistributing the benefits it may bring.

The MPRDA represents the pinnacle in the development of the right of the state to intervene in matters pertaining to the subsurface of land without nationalising the resources located there. It provides that mineral and petroleum resources belong to the nation, with the state - as custodian - responsible for ensuring that these resources are exploited for the

22 Discussed fully in $H$ Mostert, $\mathrm{n} 10,78$.

23 Mineral and Petroleum Resources Development Act 28 of 2002.

24 MO Dale, L Bekker, FJ Bashall, M Chaskalson, C Dixon, GL Grobler and CDA Loxton, South African Mineral and Petroleum Law, Durban, (2005) MPRDA-137.

25 Agri South Africa $v$ Minister of Minerals and Energy; Van Rooyen $v$ Minister of Minerals and Energy 2010 (1) SA 104 (GNP) (abbreviated: AgriSA interlocutory); Agri South Africa v Minister of Minerals and Energy and Another 2012 (1) SA 171 (GNP) (abbreviated: AgriSA a quo); Minister of Minerals and Energy $v$ Agri South Africa 2012 (5) 1 (SCA) (abbreviated: AgriSA SCA); Agri South Africa $v$ Minister for Minerals and Energy 2013 (4) SA 1 (CC) (abbreviated: AgriSA CC).

26 Agri SA SCA [80]. 
benefit of the nation as a whole. ${ }^{27}$ The transitional provisions of the MPRDA determined how the switch from the dispensation under a previous law, the Minerals Act of $1991,{ }^{28}$ to the current MPRDA dispensation would occur. The "pre-existing ${ }^{29}$ rights, i.e. those which existed before the MPRDA entered force, were substituted automatically with transitional rights. ${ }^{30}$ These enabled their holders to continue benefitting from the rights by meeting certain administrative requirements. ${ }^{31}$ In the process the system of state custodianship of mineral resources was introduced. ${ }^{32}$ The litigation by Agri SA challenged these provisions and was aimed at establishing whether these provisions caused expropriation of property rights endorsed by previous mineral laws. ${ }^{33}$

The case is important for the potential impact it has on how mineral law, property law and the transformative goals of the state are to be understood. In the Constitutional Court judgment, Mogoeng Mogoeng $C J$ expressed the court's awareness of the impact of this case clearly in his reasons for granting leave to appeal: not only the parties (the Minister and Agri South Africa) had an interest in the outcome of the case, but landowners, previous holders of mineral rights, the mining industry at large, and indeed everyone who, through the MPRDA, had for the first time ever any real chance of accessing the wealth contained in South Africa's mineral and petroleum resources. ${ }^{34}$

The MPRDA is nothing if not an attempt to 'break through the barriers of exclusivity to equal opportunity, ... wealth-generation, economic development and power.' ${ }^{35}$ It represents a sophisticated attempt to address the economic injustices of South Africa's past in a way that treats individual property rights with respect. It does so by effecting an institutional change to the South African mineral and petroleum law regime. ${ }^{36}$ But the MPRDA is not flawless, and leaves much to be desired, which rendered a difficult case even harder to decide. Moreover, the judiciary felt itself in unchartered territory. Froneman $J$ in the CC ac-

\section{S 3(1), MPRDA.}

28 Minerals Act 50 of 1991.

29 This is my term, used to ease the discussion of and distinction between rights that existed before the MPRDA entered into force in 2004, and rights that did not. It is not used widely in literature on mineral law, nor in statute.

30 PJ Badenhorst, The make-up of transitional rights to minerals: Something old, something new, something borrowed, something blue...?, SALJ 128 (2011) 763, 764-766; H Mostert, n 10 , 94-95 and further PJ Badenhorst and H Mostert, Revisiting the transitional arrangements of the Mineral and Petroleum Resources Development Act 28 of 2002 and the constitutional property clause (Part One), Stellenbosch Law Review 14 (2003) 377, 380-384.

31 See P Badenhorst, SALJ 128 (2011) 763 and H Mostert, n 10, 93-101.

32 Mineral and Petroleum Resources Development Act 28 of 2002, s 3.

33 P Badenhorst, SALJ 128 (2011) 763, 782-783; H Mostert, n 10, 104.

34 Agri SA CC [22].

35 Agri SA CC [73].

36 Agri SA CC [91]. 
knowledged that 'large-scale transformational legislation [like the MPRDA] presents challenges of a special kind ${ }^{37}$ for which there is no binding precedent.

The finding of the Supreme Court of Appeal (SCA) and the Constitutional Court (CC) was that the MPRDA's provisions did not bring about expropriation of pre-existing positions. ${ }^{38}$ This was motivated by, among others, an historical analysis of the mineral laws of South Africa by the SCA, ${ }^{39}$ and a consideration of the transformative purposes of the MPRDA by the CC. ${ }^{40}$ In doing so, the South African judiciary turned some of the most generally accepted truths about South African mineral law inside-out.

Though some of their findings and some strands of the various courts' reasoning may be contested, what the set of decisions demonstrate really well, is how the concept of 'mineral right' has been misunderstood for decades. This is perhaps illustrated best by the CC judgment in the AgriSA matter. The CC treated the right to minerals as a separate form of ownership. It did so by unceremoniously breaking with traditional conceptions of the right ${ }^{41}$ without any analysis, merely acknowledging the potential of the terminology to mislead. ${ }^{42}$ In the face of the other, apparently bigger or more serious questions, the CC's lack of reasoning on this point may seem inconsequential. But it is not. Considered together with another omission - the Court's refusal to conceptualise the idea of state custodianship - the lack of reasoning weakens the entire structure of the MPRDA, a matter which the Court is at pains to protect. It also led the Court astray on the 'technical' questions relating to the constitutional property clause. The latter two points cannot be elucidated here further, for lack of scope. This contribution focuses only on the one aspect dealing with how the right to minerals could be conceptualised, in relation to the state's powers of mineral resources.

The main judgment of the CC in AgriSA decided to opt for an interpretation that views the nature of the right to minerals as being in the line of ownership, and the entitlement not to mine, or the ability not to exploit minerals as essential components thereof. ${ }^{43}$ Mogoeng Mogoeng CJ's intuition about the nature of the right is correct; but not grounded in an appropriate analysis and hence prone to criticism. This essay attempts to provide some of the required analysis.

In what follows, a closer look is taken at this concept of 'mineral right:' its origins and make-up, its rise and fall. Of particular interest are the consequences of the choices made in conceptualising the right, and the implication for modern interpretation of related terminology. In the process, the different approached adopted by the SCA and CC are used to illustrate deeply embedded erroneous assumptions about the core notion of 'mineral right' influ-

37 Agri SA CC [91].

38 Agri SA SCA [99]-[100].

39 Agri SA SCA [23] - [76].

40 Agri SA CC [69]- [70].

41 Agri SA CC [39].

42 Agri SA CC [38].

43 Agri SA CC [43]. 
enced the litigation in the AgriSA matter. The analysis begins with a discussion of a key aspect of South African mineral law, juridical severance of mineral rights from ownership. It then proceeds to consider the nature of the rights thus created. The next step is to compare these rights with those contemplated in the MPRDA. Some of the consequences of the conceptual shift introduced by the MPRDA are then explored, before the impact of the AgriSA decision is highlighted.

\section{Cuius est solum and the mechanism of juridical severance}

When explorations to uncover South Africa's mineral wealth began after $1867,{ }^{44}$ the country's mineral law consisted of no more than a few standard Roman-Dutch principles of property law, supplemented by British colonial policy, and the practice as reflected in the Cradock Proclamation, of reserving mineral rights to the state upon the grant of land. ${ }^{45}$ The position was even more rudimentary in the Boer republics, ${ }^{46}$ where a reservation similar to that of the Cradock Proclamation did not apply. In very general terms, save where they were reserved for the Crown or the State, mineral rights formed part of the rights of the landowner, ${ }^{47}$ emanating from the entitlement to use and enjoy the land, its attachments and subsurface.

The rapidly developing mining industry necessitated some urgent changes to this state of affairs. Costliness precluded many individual landowners from undertaking prospecting and mining operations. ${ }^{48}$ A mechanism was needed that would allow landowners to exploit their rights better, allowing them to retain the benefit of the land surface whilst alienating the rights to the subsurface to those financially better situated to exploit the subsurface resources. The Cradock proclamation, ${ }^{49}$ reserving mineral rights in respect of precious stones, gold and silver to the Crown upon the grant of land, ${ }^{50}$ had already supported the idea that mineral rights can exist independently from the ownership of the land in which they are found. In fact, severance of mineral rights from landownership was a notion known already

44 H Giliomee and B Mbenga, New history of South Africa, Cape Town, (2007) 486.

45 CG Van der Merwe, n 16, 553, with reference to Sir John Cradock's Proclamation on Conversion of Loan Places to Quitrent Tenure, 1813 (6.8.1813).

46 CG Van der Merwe, n 16, 587-588. It was around this time the first 'gold law' of the Transvaal was enacted (Law 1 of 1871). See H Mostert, n 10, 16.

47 Agri $S A$ interlocutory [7].

48 CG Van der Merwe, n 16, 553.

49 Section 4, Proclamation on Conversion of Loan Places to Quitrent Tenure, 1813 (6.8.1813).

50 CG Van der Merwe, n 16, 553; J Scholtens, n 18, 576; MO Dale, South Africa: Development of a new mineral policy, Resources Policy 23 (1997) 1516. 
since medieval times, under the influence of Paulus de Castro. ${ }^{51}$ The practice soon established itself in South Africa. ${ }^{52}$

Juridical severance of the mineral rights from the surface rights of the landowner enabled third parties to become holders of rights to the subsurface resources. ${ }^{53}$ Severance entailed that the rights of mineral rights holders could be recognised, alongside those of landowners, where certain procedures had been followed. ${ }^{54}$ Generally, it involved a registration action: ${ }^{55}$ mineral rights could be reserved against the title deed of the land when it was transferred to a new owner. The reservation could be registered in the Deeds Registry, alongside the transfer of the land. ${ }^{56}$ The landowner could also retain the land, but alienate the mineral rights to another by registering a notarial deed of cession in respect of these rights. When dividing co-owned land, the mineral rights could be excluded from the partition transfers and retained in undivided shares under separate certificates of mineral rights. A landowner could also obtain a separate certificate of rights to the minerals in respect of the land, enabling him to hold title to the land separately from title to the minerals. It was also possible for the mineral rights to be expropriated separately, or independently from the landownership. In such cases a deed of cession could be registered in the Deeds Registry. Likewise, where land was expropriated, a certificate of rights to minerals had to be obtained simultaneously with lodgement of the deed of transfer. ${ }^{57}$ The consequence of juridical 'severance' was that mineral title could be recognised separately from and alongside title to the land. ${ }^{58}$

An 1881 resolution of the Transvaal Volksraad asserted that mineral rights could be separated from the dominium of the land in that part of the country. ${ }^{59}$ This was reinforced in subsequent legal regulations in 1883 and 1909. They required cession and other transac-

51 PJ Badenhorst and $H$ Mostert, Mineral and Petroleum Law of South Africa, 1 ed, Wetton, (2004) 1-4; J De Boer, De winning van delfstoffen in het Romeinse Recht, de middeleeuwse juridische literatuur en het Franse Recht tot 1810, Leiden, (1978) 175.

52 MO Dale, Resources Policy 23 (1997) 15, 15-16; H Mostert, n $10,10$.

53 Agri South Africa v Minister for Minerals and Energy 2013 (4) SA 1 (CC) [8].

54 B Hepple, Economic and racial legislation, in H R Hahlo and E Kahn (eds), The Union of the South Africa: The development of its laws and Constitution, London, (1960)761; Agri SA interlocutory [7].

55 PJ Badenhorst, $H$ Mostert and $M$ Dendy, Minerals and Petroleum, in W A Joubert (ed) LAWSA Vol 18, 2 ed Durban, (2007) para 40. Also described in H Mostert, n 10 , 10-11.

56 Section 70(1) and (2), Deeds Registries Act 47 of 1937. B Hepple, n 54, 761.

57 PJ Badenhorst, H Mostert and M Dendy, n 55 , para 40.

58 B Hepple, n 54, 761; Agri SA interlocutory [7].

59 Article 363, Resolution of the Volksraad of the ZAR, 1881 (8.11.1881), resolved that no sale of mineral rights would be lawful unless the deed of sale had been registered in the deeds registries office. HP Viljoen and PH Bosman, A Guide to Mining Rights in South Africa, Johannesburg, (1979) 9. 
tions in respect of mineral rights to be registered in the Deeds Registry. ${ }^{60}$ By 1911, the practice of severance had become firmly established, ${ }^{61}$ also due to its confirmation in case law, ${ }^{62}$ probably under the influence of similar principles in English law. ${ }^{63}$ It was confirmed by the subsequent law on registration of rights to land. ${ }^{64}$ However the nature of such severed mineral rights was not explicitly governed by statute.

In the formative years of South African mineral law, around the beginning of the twentieth century, it was largely up to the judiciary to establish and develop the core conceptual framework of South Africa's emerging mineral law. The courts had to work out the relationship between the landowner and the holders of rights to the subsurface. The nature of such rights, having been severed from the ownership of the land, was determined in the process.

\section{Nature of mineral right / title}

Under common-law property rules, ownership of the land's surface was indicative of control over the unextracted resources under the surface. For resources not specifically reserved to the state (such as crown minerals), the predominant view was that the landowner remained owner of the minerals for as long as they were not extracted. ${ }^{65}$ Mineral rights separated from the landownership were held under a separate title, even if the mineral rights and surface rights vested in one person. ${ }^{66}$ The court engaged with the content of severed mineral rights early in the twentieth century ${ }^{67}$ and indicated that mineral rights, severed from the landownership, included the entitlements to enter the land to which they related to search for minerals, and extract and remove them, if found. The mechanism of severance accordingly created the opportunity to forge new relationships in respect of land containing minerals. It introduced mineral rights holders as interested parties in all treatment of and dealings with land and minerals. Specifically in terms of the common law, the holder of a certificate of mineral rights automatically had a mineral right in respect of a portion of land, regardless of succession in title to the land. Mineral right holders could enter the land relat-

60 Section 14, Law 7 of 1883; ss 30 and 32, Registration of Deeds and Titles Act 25 of 1909 (T). See eg the account in Trojan Exploration Co (Pty) Ltd and Another v Rustenburg Platinum Mines Ltd and Others 1996 (4) SA 499 (A) 509C.

61 HP Viljoen and PH Bosman, $\mathrm{n} 59,10$.

62 Taylor and Claridge $v$ Van Jaarsveld and Nellmapius 1885-1888 (2) SAR TS 137 at 141; McDonald $v$ Versfeld 1885-1888 (2) SAR TS 234 at 236; Pearce $v$ Olivier and Others and Noyce 1889-1890 (3) SAR TS 79 at 81.

63 HP Viljoen and PH Bosman, $\mathrm{n} 59,10$.

64 See section 70(1), Deeds Registries Act 47 of 1937. This section was repealed by section 53 of the Mining Titles Registration Amendment Act 24 of 2003 (as amended by the Minerals and Energy Laws Amendment Act 11 of 2005).

65 B Hepple, n 54, 763.

66 PJ Badenhorst, JM Pienaar and H Mostert, n 10 , 693-694.

67 Van Vuren and Others $v$ Registrar of Deeds 1907 TS 289 at 294. 
ing to their rights and to search for minerals there. If any minerals were found, they could be removed, subject to the relevant statutory provisions. ${ }^{68}$

It was generally assumed that mineral rights could be regarded as limited real rights. Although these rights were indubitably real in nature, ${ }^{69}$ being enforceable against anyone purporting to interfere with the rights, the assumption that mineral rights are limited real rights (derived from the ownership of the land) is questionable. Contrary to iura in re aliena (limited real rights such as servitudes), the mineral right existed separately from the ownership of the land, and did not follow the destiny of the land, once it had been juridically severed. ${ }^{70}$ While the law of servitudes provided for the lapsing of servitudal rights once they were re-acquired by the landowner whose land they once burdened, ${ }^{71}$ the same was not true for mineral rights. Indeed, mineral rights did not fit as comfortably within the acknowledged structure or description of iura in re aliena, as prevalent opinion assumed. ${ }^{72}$ It therefore did not accord with the distinction between ownership and limited real rights.

Curiously, however, South African lawyers - judges and scholars - persisted in dealing with the right to minerals as connected to the landownership, by treating it as a limited real right in respect of land. ${ }^{73}$ The terminology used to explain it was the terminology of servitudes, despite the extraordinary dogmatic somersaults this required. ${ }^{74}$ Scholars and courts acknowledged that the idea of severance flew in the face of conventional common-law principles relating to landownership; ${ }^{75}$ however, neither the courts nor scholars were willing to conceive of the mineral right as a separate form of title. Within the framework of RomanDutch law, it was simply unheard of to acknowledge the possibility of horizontal layering of different kinds of property titles as espoused by English law. ${ }^{76}$

The superficial similarities between personal servitudes and mineral title ${ }^{77}$ rendered the courts $^{78}$ unwilling to develop the concept of mineral rights in any way other than by draw-

68 Ex Parte Pierce 1950 (3) SA 628 (O) at 634.

69 Trojan Exploration Co (Pty) Ltd and Another v Rustenburg Platinum Mines Ltd and Others 1996 (4) SA 499 (A) at 509H.

70 CG Van der Merwe, n 16, 561; PJ Badenhorst, JM Pienaar and H Mostert, n 10 , 693-694; H Mostert, n $10,11$.

71 PJ Badenhorst, JM Pienaar and H Mostert, n 10, 337-338.

72 CG Van der Merwe, n 16, 558-562.

73 PJ Badenhorst, JM Pienaar and H Mostert, n $10,667$.

74 PJ Badenhorst and H Mostert, $\mathrm{n} 51,1-9 ; 1-14 \mathrm{ff}$.

75 CG Van der Merwe, n 16, 171, 553.

76 Coronation Colleries v Malan 1911 TPD 577 at 591.

77 CG Van der Merwe, n 16, 559. See also the in-depth comparison at 560-561.

78 Taylor and Claridge $v$ Van Jaarsveld and Nellmapius 1885-1888 (2) SAR TS 137 at 141; McDonald $v$ Versfeld 1885-1888 (2) SAR TS 234 at 236; Pearce $v$ Olivier and Others and Noyce 1889-1890 (3) SAR TS 79 at 81; Lazarus and Jackson v Wessels, Oliver and the Coronation Freehold Estates, Town and Mines Ltd 1903 TS 499 (T) at 510. 
ing an analogy with personal servitudes. ${ }^{79} \mathrm{~A}$ mineral right entitled its holder to enter the land, search for minerals, extract them and remove them. ${ }^{80}$ This resembled the content of a typical usufruct. ${ }^{81}$ The mineral right holder could choose whether or not to exercise the right and could exclude others from doing so. ${ }^{82}$ To this extent there really is not much of a difference between the mineral right and the usufruct. But here the similarities end. Because of severance, mineral rights did not have to follow the juridical destiny of the land: they could be alienated separately from the land; ${ }^{83}$ they were freely transferable and inheritable, and need not have been exercised salva rei substantia. ${ }^{84}$ Unlike a servitude, mineral rights did not terminate where the landowner later (re)acquired the mineral rights. ${ }^{85}$ In addition, they were also divisible, unlike a servitude. ${ }^{86}$

A mineral right could, moreover, be the object of a usufruct, ${ }^{87}$ thus assuming the role of an incorporeal thing (res incorporales), subject to a limited real right. This construct of allowing a right to be the object of another right was something that South African law denied was possible, but nevertheless, rather inconsistently, permitted for mineral rights. The problem was that acknowledging a right as the object of another right is inconsistent with the prevalent dogma in private law: ${ }^{88}$ it is illogical ${ }^{89}$ and, some argued, jurisprudentially impossible, for instance, to lease or encumber a right of usufruct. ${ }^{90}$ In respect of minerals,

79 CG Hall, Maasdorp's institutes of South African Law: Volume II The Law of Property, 10 ed, Cape Town, (1976) 192; Neebe v Registrar of Mining Rights 1902 TS 65 at 83; RW Lee, An introduction to Roman-Dutch Law, 4 ed, Oxford, (1946) 185 - 186; B Hepple, n 54 , 764: 'personal quasi-servitudes' and 'mineral servitudes'.

80 Van Vuren and Others $v$ Registrar of Deeds 1907 TS 289 at 294; Rocher v Registrar of Deeds 1911 TPD 311311 at 316; Ex Parte Pierce 1950 (3) SA 628 (O) at 634; Aussenkjer Diamante (Pty) Ltd v Namex (Pty) Ltd 1983 (1) SA 263 (A) at 274. Le Roux and Others v Loewenthal 1905 TS 742 at 745; Van Vuren and Others $v$ Registrar of Deeds 1907 TS 289 at 295 and 316; Nolte $v$ Johannesburg Consolidated Investment Co Ltd Respondent 1943 AD 295 at 315; South African Railways and Harbours v Transvaal Consolidated Land and Exploration Co Ltd 1961 (2) SA 467 (A) at 481.

81 HP Viljoen and PH Bosman, $\mathrm{n} 59,8$.

82 Agri SA interlocutory [9].

83 CG Van der Merwe, n 16, 561; Webb v Beaver Investments (Pty) Ltd \& Another 1954 (1) SA 13 (T) at $25 \mathrm{~A}$.

84 Translation: 'The substance of the thing being saved'.

85 CG Van der Merwe, n 16, 561; Beyers en 'n Ander v Du Preez en Andere 1989 (1) SA 328 (T) at 336 .

86 CG Van der Merwe, n 16, 562.

87 Ex Parte Eloff 1953 (1) SA 617 (T).

88 CG Van der Merwe, n 16,21-22 discusses this issue and then indicates that certain exceptions should be acknowledged, most notably in the context of mineral rights. See also his further comments at 561 .

89 CG Van der Merwe, n 16, 21.

90 CG Van der Merwe, n 16, 513-514. 
however, it was acknowledged that other rights could be granted over mineral rights, ${ }^{91}$ prospecting and mining rights in respect of mineral rights being the primary example. ${ }^{92}$

On the basis of these attributes, a couple of lone scholarly voices (namely those of Viljoen and Bosman), ${ }^{93}$ advocated the recognition of mineral rights as a separate and independent class of ownership rights, removed from the servitude context. But their efforts were to no avail. With hindsight, conceiving of a mineral right as a specific kind of legal object, and hence mineral title as a separate kind of ownership right would well have been possible: South African law already deviates from its civil law counterparts insofar as it does not adhere to the principle of a closed category - a numerus clausus - of limited real right types with fixed content. ${ }^{94}$ The South African system of real rights being unregimented, it allows customised arrangements that suit the particular needs of users. ${ }^{95}$ In the absence of rules that bind users to specific types of rights with predetermined content, it could well have been possible within the South African system of rights to property to conceptualise mineral rights as a separate form of title.

Unwilling to break with convention, however, the judiciary resorted to attempts to classify rights to minerals as limited real rights within the South African unitary ownership paradigm..${ }^{96}$ But mineral rights simply did not fit any of the conventional categories of limited real rights: they were not praedial servitudes, being in favour of a person, not a dominant tenement, ${ }^{97}$ and they were not personal servitudes, because they were freely transferable. ${ }^{98}$ The judicial solution for this conundrum was to refer to mineral rights as 'quasiservitudes', ${ }^{99}$ a 'label that ... stuck' ${ }^{100}$ even though scholarship remained highly critical of it.

91 PJ Badenhorst, JM Pienaar and H Mostert, n 10, 667.

92 Du Preez v Beyers en Andere 1989 (1) SA 320 (T) at 324F-G; PJ Badenhorst, Exodus of 'mineral rights' from South African Mineral Law, Journal of Energy and Natural Resources Law 22 (2004) 218222.

93 HP Viljoen and PH Bosman, $\mathrm{n} 59,20$.

94 MJ De Waal, Numerus clausus and the development of new real rights in South African Law, (1999) 4.

95 It acknowledges such tailor-made rights as 'real' and registrable if the correlative obligations created by the rights burden the land. In other words, if the obligation rests upon the landowner in a personal capacity (i.e. does not burden the landowner because of the fact of landownership) then the right is personal and not registrable. Ex parte Geldenhuys 1926 OPD 155 at 164. See also Pearly Beach Trust v Registrar of Deeds 1990 (4) SA 614 (C) and Lorentz v Melle 1978 (3) SA 1044 (T). H Mostert and LCA Verstappen, Practical approaches to the numerus clausus of land rights, in Warren Barr (ed) Modern studies in Property Law, Oxford, (2014) forthcoming.

96 PJ Badenhorst, JM Pienaar and H Mostert, n 10 , 693-695; H Mostert, n 10 , 9-11, 36-37.

97 PJ Badenhorst, JM Pienaar and H Mostert, n 10, 323.

98 PJ Badenhorst, JM Pienaar and H Mostert, n 10, 695; H Mostert, n 10, 14.

99 PJ Badenhorst, JM Pienaar and H Mostert, n 10 , 694-695; H Mostert, n 10 , 36-37.

100 Trojan Exploration Co (Pty) Ltd and Another v Rustenburg Platinum Mines Ltd and Others 1996 (4) SA 499 (A) 509G-H. 
Scholarship itself, however, refused to allow a separate conceptual space for these rights. The debate could never break out of the mould of a unitary Roman-Dutch conception of ownership. It refused even to entertain the idea that there can be several types of property right one can hold in respect to one's own property. Instead, what dispute there was about the mineral right as a form of real right, was focused on explaining the nature of this peculiar right within the parameters of the ius in re aliena, rather than the ius in re propria. ${ }^{101}$ So, while the judiciary opted for a description of juridically severed mineral rights as 'quasi-personal' servitudes, ${ }^{102}$ prominent scholars veered towards an explanation of these rights as 'sui generis'. ${ }^{103}$ The disagreement was never really resolved.

In the AgriSA matter, the $\mathrm{CC}$ had the opportunity to set the record straight, and in a way has done so, with its endorsement of the idea of rights to minerals as a form of title - a ius in re propria - albeit without any justification other than that the situation was 'confusing'. By opting to label the mineral rights that preceded the MPRDA as a distinct form of ownership ('title'), the CC set itself apart from the other branches of the judiciary that had to pronounce on the matter. The court a quo followed the conventional line of thinking, operating within the paradigmatic understanding of mineral right as a ius in re aliena. There is, however, another consideration crucial to conceptualising mineral title in the manner in which the $\mathrm{CC}$ uses the term. It is implicit in the reasoning of the $\mathrm{CC}$, but really elaborated much more fully in the SCA's reasoning. The SCA's judgment was founded much more directly on its cognisance of the public-law basis of the right to mine. This latter approach needs further attention.

Analyses treating the mineral right as a servitude, rather than as a separate form of title (in the sense of ownership, rather than limited real rights), demonstrated the weakness of a purely private-law approach to the conceptualisation of mineral rights. In reality, there was an important public-law aspect to the term 'mineral right' which these analyses denied by implication. It is necessary to explore this point, because a purely private-law approach to this category of rights in all of a century did not manage to explain the notion of mineral rights satisfactorily. The inexplicable unwillingness of our law to accept the idea that ownership (title) may take different forms ${ }^{104}$ caused a long-standing denial of the distinct public-law dimension of these rights; or rather, caused the important public-law aspect to pass by unacknowledged in those contexts where the nature of the right was discussed. ${ }^{105}$ Only

101 PJ Badenhorst, The revesting of state-held entitlements to exploit minerals in South Africa: Privatisation or deregulation, Tydskrif vir die Suid Afrikaanse Reg (1991) 113, 117; H Mostert, $\mathrm{n}$ 10,9 .

102 Van Vuren and Others $v$ Registrar of Deeds 1907 TS 289. H Mostert, n 10 , ch 2.

103 CG Van der Merwe, n 16, 561; HP Viljoen and PH Bosman, n 59, 20-21.

104 See above. Also e.g. Van Vuren and Others v Registrar of Deeds 1907 TS 289 296-297 and Nolte v Johannesburg Consolidated Investment Co Ltd Respondent 1943 AD 295 in which mineral rights were referred to as a 'mineral servitude' and a 'quasi-servitude' respectively. Such decisions do not entertain the possibility that a mineral right is actually a different form of title.

105 H Mostert, n 10, 159. 
when the AgriSA matter came to a head in the SCA this public-law element of the mineral right really received attention. In the $\mathrm{CC}$, this aspect is implicit, but underplayed.

\section{Public law dimension of mineral rights}

A vitally important feature of the severed mineral right has remained unmentioned up to now: this is that the exercise of mineral rights depended, to a very large extent, on whether and how the state permitted such action.

\section{A. Historical justification}

Although the content of the mineral right included the entitlement to search for and extract (mine for) minerals, there was a significant limitation on this right. ${ }^{106}$ To be able to prospect and mine, the mineral right holder had to have the permission of the state. ${ }^{107}$ This permission took different forms in different generations of mineral law. ${ }^{108}$ To understand this better, it is necessary to consider how the regulatory powers of the state were exercised in respect of mineral resources. A study of the various generations of mineral law demonstrate that regulatory intensity varied, depending on the type of mineral at stake, and where in the country the particular resources were situated. ${ }^{109}$

From a regulatory point of view, precious metals and stones were obviously jealously guarded, even from the earliest days of the Gold Rush, despite large disparities in how this was done among the different colonies and the Boer republics. ${ }^{110}$ After unification in 1910, incrementally, the state's control over the mining industry and mineral resources was affirmed and extended from precious stones and metals to base minerals, oil and gas. ${ }^{111}$ Heavily dependent on what type of mineral was at stake, the activation of mineral rights involved the intervention of the state. ${ }^{112}$ Because mineral resources are so crucial to a country's economy, it is to be expected that their extraction must occur in a way that serves the national interest. ${ }^{13}$ What is in the national interest may involve environmental, health and safety concerns, or social transformation, or other choices - involving the concerns of a

106 JD Van der Vyver, Nationalisation of mineral rights in South Africa, De Jure 1 (2012) 125; HM Van den Berg, Ownership of minerals under the new legislative framework for minerals, Stellenbosch Law Review 20 (2009) 137.

107 JD Van der Vyver, De Jure 1 (2012) 127; HM Van den Berg, n 106, 141-143.

108 H Mostert, n $10,19-38$.

109 H Mostert, n $10,19-115$.

110 See E Van der Schyff, South African mineral law: A historical overview of the state's regulatory power regarding the exploitation of minerals, New Contree (2012) 131 135-146.

111 HM Van den Berg, n 106, 139, 142; B Hepple, n 54, 764-770; natural oil included combustible gas in terms of the Mining Rights Act 20 of 1967, see H Mostert, n 10, 41.

112 HR Hahlo and E Kahn, The Union of South Africa, London, (1960) 764.

113 CG Van der Merwe, n 16, 568, 575; H Mostert, n 10, 129. 
particular society at a given point. ${ }^{114}$ The choice is always political, and it may consider private interests, or not. ${ }^{115}$

A study across the four generations of South African mineral law show that the right to prospect and mine was regulated by the state in different ways, to serve different policy choices. ${ }^{116}$ The common denominator across all four generations, however, is that state regulation was constitutive of a right holder's ability to prospect or mine at all. This point is made well by the Supreme Court Appeal in the AgriSA matter. ${ }^{117}$

\section{B. Affirmation in Agri SA v Minister of Minerals and Energy}

In the SCA judgment, the pertinent question was about whether previous holders of unexercised mineral rights were expropriated of their rights with the coming into force of the MPRDA and its transitional provisions, where they did not timeously convert their substitute transitional rights into types of rights acknowledged by the MPRDA.

The SCA decided this in the negative. ${ }^{118}$ The majority judgment decided that no expropriation occurred, for the reason that one of the essential elements of expropriation was not established. ${ }^{119}$ In particular, it was the fact that the right to mine never vested in the holders of mineral rights without state intervention that induced the majority of the Court to hold that no deprivation of property could be established. ${ }^{120}$ This consideration, alongside that the state had not acquired any rights, ${ }^{121}$ supported the Court's finding that no expropriation occurred. Comparing the position in which mineral rights placed their holders before the MPRDA with their position thereafter, ${ }^{122}$ the Court noted that the state was in no different position. ${ }^{123}$ A minority concurring judgment accepted that the MPRDA extinguished com-

114 H Mostert, n 10, 157-159; PJ Badenhorst, H Mostert and M Dendy, n 55, para 1.

115 H Mostert, n $10,157$.

116 PJ Badenhorst, H Mostert and M Dendy, n 55, para 1; H Mostert, n 10, 157 - 158.

117 Minister of Minerals and Energy v Agri South Africa 2012 (5) 1 (SCA) [90], [99]. See further PJ Badenhorst, Large scale expropriation of mineral rights in South Africa: The Agri South Africa fiasco, Australian Resources and Energy Law Journal 31 (2012) 205; PJ Badenhorst, Expropriation of "unused old order rights" by the MPRDA: You had nothing!, THRHR 76 (2013) 472; JD Van der Vyver, De Jure 1 (2012) 125.

118 Wallis JA (with whom Heher and Leach JJA concurred) wrote the majority judgment. Nugent JA (with whom Mhlantla JA concurred) concurred with the majority of the court, but for different reasons: see Minister of Minerals and Energy v Agri South Africa 2012 (5) 1 (SCA) [117].

119 Agri SA SCA [90].

120 Agri SA SCA [85], [99].

121 Agri SA SCA [85], [90].

122 Agri SA SCA [76], [84]-[85].

123 Agri SA SCA [76], [84]-[85]. 
mon-law mineral rights, ${ }^{124}$ but explicitly denied that common-law mineral rights entailed the ability to exploit the resources. ${ }^{125}$

On appeal to the CC, ${ }^{126}$ the outcome of the SCA decision was upheld, but for very different reasons. The majority of the CC decided, through Mogoeng Mogoeng $C J{ }^{127}$ that the MPRDA deprived holders of unused old order rights of some aspects of mineral rights they used to have, ${ }^{128}$ but denied that such deprivations amounted to an expropriation, since the state did not acquire what the holders lost. ${ }^{129}$

The decision indicates that the state assumed custodianship of mineral resources on behalf of 'all the people of South Africa' and the MPRDA empowered it to grant rights to others that could previously have been granted by holders of mineral rights. But nevertheless, the state did not acquire any mineral rights: ${ }^{130}$ '(n)either the State nor other entities or people acquired the rights to sterilise, monopolise the exploitation of minerals or sell, lease or cede Sebenza's old order rights on 1 May 2004'. ${ }^{131}$ The CC, like the SCA before it, deemed it unnecessary to define 'state custodianship'. ${ }^{132}$ All the CC was willing to admit, is that, 'whatever 'custodian' means, it does not mean that the state has acquired and thus has become owner of the mineral rights concerned. ${ }^{133}$ By the CC's own admission, ${ }^{134}$ the notion of custodianship plays an important part in the overall justification of its ruling: Because of the pivotal ruling that an expropriation must be accompanied by an acquisition of rights by the state, it is important for the court to consider (a) what was lost, and (b) what was gained, through the process of the MPRDA.

The CC's answer to the first question was that mineral title (i.e. ownership), which may have had an indeterminate value, was lost. Whereas the CC's intuition about the nature of the right here is correct, the implication is far-reaching: For a ruling to uphold the MPRDA,

Agri SA SCA [112].

125 Agri SA SCA [113].

126 Agri SA CC [68], [71].

127 Moseneke DCJ, Jafta J, Nkabinde J, Skweyiya J, Yacoob J and Zondo J concurring.

128 Agri SA CC [51], [2].

129 See Agri SA CC [66]-[68], [71].

130 Agri SA CC [68], [71].

131 Agri SA CC [71]. The two concurring minority judgments deviated from the reasoning of the majority on the point of state acquisition as a requirement of expropriation, and on the question of whether the state had acquired rights under the MPRDA. Cameron J concurred with the reasoning of the majority, but pointed out that acquisition by the state is not a necessary feature of expropriation under section 25 of the Constitution. Agri SA CC [78]. In a separate judgment Froneman J with Van der Westhuizen J concurring held that the state acquired some entitlements previously belonging to mineral right holders of unused old order rights; but that the transitional arrangements, as 'compensation in kind', constituted 'just and equitable compensation' in terms of section 25(3) of the Constitution. Agri SA CC [79], [88], [90], [102], [106].

132 Agri SA CC [71].

133 Agri SA CC [71].

134 Agri SA CC [68]. 
when challenged from a position that a right as strong as ownership was lost, the arguments need to be really persuasive. The CC finds that persuasion in the transformative purposes of the Constitution, and through it also the MPRDA.

The CC nailed its pro-redress colours to the mast from the start, did not rely fully on the mechanisms of justification at its disposal. Having found that ownership of minerals was lost; and in trying to establish whether this constituted an expropriation, the main judgment turns to interpreting the 'special role' of the constitutional property clause ${ }^{135}$ 'in facilitating the fulfilment of our country's nation-building and reconciliation responsibilities'. ${ }^{136}$ It specifically notes the Constitution's recognition of 'the need to open up economic opportunities to all South Africans'. ${ }^{137}$ Against this background, the CC indicated that the balancing exercise between private and public interests, to be undertaken in terms of the constitutional property clause, cannot result in an over-emphasis on 'private mineral ownership rights ... at the expense of the urgent and critical need to open up equitable access to ... our mineral and petroleum resources.' 138 Essentially, for the CC, it was the transformative purpose of the MPRDA that immunised it from constituting a compensable taking. This motivation underlies its ruling that the infringement on property rights brought about by the MPRDA did not amount to an expropriation, as it did not entail that the state acquired substantially similar rights to those lost.

While the CC's transformation argument is laudable, it could have been made even more compellingly in reliance on the nature of the right at stake and its relationship with the State's custodial duties as espoused by the MPRDA. The context in which this could have been done is the appropriateness of the deprivation at stake in the case. Here the transformation argument could be employed to great effect, to justify even significant inroads on property, without compromising perceptions of mineral tenure security. Had more attention been paid to (1) the question of why the right to minerals need to be construed as a form of ius in re propria; and (2) what state custodianship really means, the Court's course of argument might very easily have led to greater, and more appropriate, focus placed on the question whether the imposition complained of here amounted to an arbitrary deprivation of property. To illustrate the kind of reasoning that would have supplemented the transformation argument, one may return to the judgment of the SCA, and to the work of an eminent property theorist pertaining to the relationship between state authority and private rights.

135 S 25 of the Constitution, 1996.

136 Agri SA CC [60].

137 Agri SA CC [60].

138 Agri SA CC [70]. 


\section{Relationship between state and private actors}

Scholars criticised the outcome and reasoning of the CC decision. ${ }^{139}$ Some of the objections against the decision are informed by different views as to the state's regulatory powers and the extent to which that may interfere with private proprietary positions. Closer analysis of these criticisms reveals that they are inadvertently based on differing assumptions about the relationship between absolute use-powers of private parties and control-powers of the state relating to property. Underkuffler ${ }^{140}$ explains the various combinations well: depending on how a legal system views the state's sovereignty over natural resources, (1) the state may grant 'full-blooded' (i.e. extensive and all-encompassing) powers and privileges to private parties, which may then be restricted through property-limiting rules; or (2) the state may grant limited or 'lesser' powers and privileges from the outset, which may then be limited further in the same way as in (1) mentioned; or (3) a private party may be granted either option 1 or option 2 type powers and privileges, understanding that when circumstances change it will influence the scope of those powers and privileges.

The private-law analysis of the nature of mineral rights (discussed above) that has hitherto dominated conceptualisations of South African mineral law tempts interpretations that are based on option 1 type understandings of the relationship between the state and private parties when it comes to mineral resources. Typically, criticisms based on a purely privatelaw view of the proprietary aspect of mineral rights ${ }^{141}$ revert to descriptions of the rights lost in ways resembling the conventional private-law description of ownership and real rights. From this point of view, conclusions objecting against the route taken by the SCA and the CC seem logical at first, until it is recalled that even the private-law basis for mineral rights was severely restricted by statute as soon as first significant discoveries of mineral resources were made, all across the South African territory. ${ }^{142}$ Such criticisms conveniently ignore the multifaceted governmental control over mineral resources that was in place across several generations of mineral law. ${ }^{143}$

139 PJ Badenhorst, Onteiening van onbenutte ou-orde regte: Het iets niets geword? Agri South Africa v Minister of Minerals and Energy 20134 SA 1 (KH), THRHR 77 (2014) 313; I Rautenbach, Expropriation and arbitrary deprival of property: Five forensic constructions - Agri South Africa $v$ Minister for Minerals and Energy 20137 BCLR 727 (CC), 20134 SA 1 (CC): Regspraak, TSAR (2013) 743 745-757; E Van der Schyff and N Olivier, Vonnisbespreking: 'n Perspektief op die impak van die Mineral and Petroleum Resources Development Act 28 van 2002 op voorheen bestaande regte, LitNet 11 (2014) 52, 61-65.

140 L Underkuffler, The idea of property, Oxford, (2003) 57.

141 PJ Badenhorst, THRHR 77 (2014) 313; PJ Badenhorst, THRHR 76 (2013) 472; PJ Badenhorst, Australian Resources and Energy Law Journal 31 (2012) 205; PJ Badenhorst, Expropriation of unused old order rights by the MPRDA: You have lost it!, THRHR 75 (2012) 329; JD Van der Vyver, De Jure 1 (2012) 125.

142 E Van der Schyff, New Contree (2012) 131ff.

143 See especially H Mostert, n 10 , ch 3 and 4. 
Moreover, such criticisms seem to be based on erroneous assumptions about the scope of the state's domainial powers ${ }^{144}$ over resources in the South African territory. In AngloAmerican (common-law) jurisdictions, the understanding of the relation between state sovereignty and property claims seems to accord with option 1 , in as far as the subsurface is concerned. ${ }^{145}$ In civil-law jurisdictions, however, option 2 seems to enjoy precedence when it comes to the subsurface. ${ }^{146}$ Mineral title does not ordinarily go to a landowner on first grant of the land. The state retains sovereignty over the resource. Roman-Dutch law, which forms the basis of the South African legal system, was not particularly well developed on this point, because of the dearth of exploitable resources in the countries from which South Africa inherited its legal rules. ${ }^{147}$ Although academic authority on this point may be scarce and difficult to access, what is available is persuasive: in Roman and Roman-Dutch law the state's authority to control the extraction of mineral resources was beyond doubt. ${ }^{148}$ In some colonial jurisdictions modelled on civil law the connection is clear. Namibia, following the cue of its main colonial influence Germany, has this approach, ${ }^{149}$ as do all of the jurisdictions in South America. ${ }^{150}$ The South African system is rather conflicted in this respect: South African property law is so strongly modelled on civil law. ${ }^{151}$ Yet, strangely, interpretations dealing with the relationship between the state and private actors in respect of rights over natural resources ignore the important foundational consideration: ${ }^{152}$ that based on the legal system's roots in civil law, sovereignty over natural resources should be

144 An excellent discussion of various models of sovereignty can be found in JJ González, Civil law treatment of the subsurface in Latin American countries, in Donald Zillman, Aileen McHarg, Lila Barrera-Hernández and Adrian Bradbrook (eds), The Law of Energy Underground, 1 ed Oxford, (2014) $69 \mathrm{ff}$.

145 See PJ Badenhorst, THRHR 75 (2012) 329 for a description of the powers and privileges of US mineral owners; See B Barton, The common law of subsurface activity: General principle and current problems, in Donald Zillman, Aileen McHarg, Lila Barrera-Hernández and Adrian Bradbrook (eds), The law of energy underground, 1 ed Oxford, (2014) for a description of the role of cuius est solum and the precedence of mineral title for Australia, New Zealand and the UK.

146 Regardless of whether a particular country is based on a regalian or domanial system of sovereignty. See JJ González, (n 144 ) 69-70.

$147 J$ De Boer, n $51,2-10$.

148 J De Boer, n 51, 93-137, 267.

149 H Mostert and H Van den Berg, Roman-Dutch Law, custodianship and the African subsurface: The South African and Namibian experiences, in Donald Zillman, Aileen McHarg, Lila BarreraHernández and Adrian Bradbrook (eds), The Law of Energy Underground, 1 ed Oxford, (2014) 80-85.

150 JJ González, n 144, 69ff.

151 R Zimmermann and D Visser, Introduction: South African law as a mixed legal system, in $\mathrm{R}$ Zimmermann and D Visser (eds), Southern Cross: Civil Law and Common Law in South Africa, Cape Town, (1996) 28 refer to South African property law as 'the most unassailable stronghold of civilian jurisprudence' in South African law.

152 PJ Badenhorst, THRHR 75 (2012) 329, 336-343; PJ Badenhorst, THRHR 76 (2013) 472, 485-490; JD Van der Vyver, De Jure 1 (2012) 125-138. 
expected to lie with the state. Instead, for more than a century, South African courts and scholarship relied heavily, and apparently erroneously, on the 'full-blooded' absolute powers and privileges encompassed by a common-law understanding of cuius est solum. The confusion may be explained with reference to the mixed roots of modern South African law, ${ }^{153}$ but that does not offer clarity going forward, and it does not explain the dogmatic inconsistencies that have inhabited the South African understanding of the nature of the right to minerals for more than a century.

There seems to be different interpretations of how exactly the state's regulatory involvement in mineral rights should influence the nature of those rights. To understand these varying interpretations, it is necessary to keep the earlier prevalent, private-law orientated dispensation in mind. In my view, in the past, the extraction of minerals depended on a dual legal layer: The one layer concerned access to the mining industry, which was controlled by the proprietary nature of the mineral right holder's rights. ${ }^{154}$ These rights were determined under common law. ${ }^{155}$ The other layer was about activation of those rights, which concerned the state's regulatory regime for minerals, and was supported by administrative law mechanisms. ${ }^{156}$ The MPRDA eradicated the boundaries between these layers by giving the state administrative powers and functions to determine both access to the industry and how rights thus obtained could be activated. ${ }^{157}$

The SCA decision in Agri SA viewed the construction differently: It limited the privatelaw aspect of the mineral right by indicating that the common law allows the landowner only to confer a personal right on some other person to remove and extract minerals. ${ }^{158}$ The SCA's stance ${ }^{159}$ was that the right to remove and extract minerals became a real right through judicial development, reinforced by statute. ${ }^{160}$ Mineral rights, the court indicated, were founded on the right to mine. ${ }^{161}$ What private rights there were at the time that the MPRDA came into force, were wholly dependent on the authority granted by the state. This is, in essence an inversion of the dual layer (access/activation) explanation set out above. It

153 On the mixed legal system that characterises South African law, see $R$ Zimmermann and DP Visser, $\mathrm{n} 151,1-30$.

154 H Mostert, n $10,94$.

155 See M Kaplan and MO Dale, A Guide to the Minerals Act 1991, Durban, (1992) 5-6.

156 See section 5 of the MPRDA which defines the legal nature of prospecting and mining rights. Section 6 of the Act applies the principles of administrative justice to any acts or decisions taken in terms of the Act. Chapter 4 of the MPRDA concerns applications for rights, the granting of rights and the transferability of rights. See MO Dale, L Bekker, FJ Bashall, M Chaskalson, $C$ Dixon, GL Grobler and CDA Loxton, n 24 , MPRDA-136 to MPRDA-152, MPRDA-155ff MPRDA-460 for commentary on the relevant provisions. See also H Mostert, n 10, 94.

157 H Mostert, n $10,95$.

158 Agri SA SCA [33] and [61] - although this is difficult to reconcile with his statement that the right to mine vested in the State under Roman law.

159 Agri SA SCA [39], [49] - [52], [63], [68] and [83].

160 Agri SA SCA [59].

161 Agri SA SCA [28]. 
goes like this: A mineral right was actually only really fully in existence if it was accompanied by the state authorisation to mine. ${ }^{162}$ Before that point, no consequences could attach to the right. ${ }^{163}$ This approach of the SCA is strongly reminiscent of the option 2-type approach to the managing of mineral resources in the hands of private actors.

There is room to criticise the analysis of the SCA, ${ }^{164}$ but the reasoning was strong in respect of the relationship between the state's sovereign powers over resources and the role of private actors. First, the SCA's chosen point of departure enabled the court to take a robust stance against AgriSA's argument that all those mineral right holders who were not actively exercising their rights when the MPRDA entered into force, were expropriated. ${ }^{165}$ Second, the SCA's opinion on at least one crucial point is correct: the value of mineral rights was derived from the allocation of the right to mine. ${ }^{166}$ Third, the SCA's final analysis is correct: when the legislature decided to abolish the existing system and reallocate the right to mine, the change did not amount to a blanket deprivation of all who previously held or exercised any mineral right. ${ }^{167}$

The court's interpretation of the relation between the right to prospect or mine in relation to the common law mineral right may be questioned, however. Viewed from the private-law inspired analyses that several of the academic commentators followed in their subsequent evaluation of the AgriSA decisions, the SCA's stance that a mineral right in its entirety was dependent on the gift of the state denies that in considerable parts of the country the right to minerals was not explicitly reserved for the state in legislation. ${ }^{168}$ The Cradock proclamation applied only to that part of the country under British control before the Great Trek and the Anglo-Boer War. ${ }^{169}$ For considerable parts of the country, and for significant types of minerals, it is unclear whether the right to prospect and mine was, in fact, originally an aspect of the common-law mineral right. ${ }^{170}$ The domainial sovereignty model supported by civil law would suggest that it was not, and that the power to control extraction of resources must have been in the hands of the state, if the model of state sovereignty is to

162 Section 5(2),Minerals Act 50 of 1991.

163 M Kaplan and MO Dale, n 155, 17.

164 The context of the AgriSA as a test case certainly contributed to rendering it a problematic judgment to hand down in any event. The SCA's reasoning basically obliterated any possibility of relief for a holder who suffered extreme hardship upon the entering into force of the MPRDA to claim compensation for such, as is foreseen by the Act. The kind of legislative change brought about by the MPRDA, and the severity of certain regulatory choices may have a particularly harsh effect on some holders, and not others. If the courts were to deal appropriately with such severe hardship, it would be necessary to take a far less categorical stance on issues about what was lost when the MPRDA was introduced.

165 Agri SA SCA [65] - [76].

166 Agri SA SCA [69].

167 Agri SA SCA [73] and [97].

168 H Mostert, n $10,81$.

169 PJ Badenhorst, An introduction to the Law of Minerals, Sunnyside, (2000) 1-20 to 1-21.

170 See $B$ Hepple, n 54, 760-762. 
accord with the civil-law basis of proprietary rules in all colonised areas of the South African territory. Although prevalent opinion would have the right to prospect and mine be a regulated component of a 'full-blooded', all-encompassing power embedded in private property law, a closer look reveals that the scope of the right to prospect or mine was determined by the state, and these determinations had varied from time to time, across different legislative periods. ${ }^{171}$ Contrary to the popular assumption, therefore, mineral resources seem to have been governed by an option- 3 type approach to the relationship between the state and private actors, if not the option 2-type model that lies at the basis of the SCA's reasoning in AgriSA.

One may ask whether there is any value in focusing on the minutiae of an argument about the nature and origin of the right to mine and its relationship to the common-law mineral right. It may seem as if engagement with these slightly differently nuanced interpretations would be of mere academic interest and it may seem as if the different interpretations would all have led to the same outcome in AgriSA in any case. However, the impact of these judgments potentially extend far beyond the immediate context of the transition from one mineral law dispensation to another. The AgriSA matter allowed the property law matrix of mineral law to be questioned. The SCA was willing to invert prevalent thinking in this respect quite drastically, holding that the basis of proprietary rights to minerals had always been the right to prospect and/or mine, and not vice versa. The SCA decision hence bravely acknowledges an aspect of the relationship between state sovereignty over resources and the role of private actors, by its recognition that any proprietary rights to mineral resources stemmed from the original gift of the state. There is some historical justification for this viewpoint, but also several exceptions in the extremely diversified system of mineral resource regulation in the various earlier generations of mineral law that preceded the MPRDA. ${ }^{172}$

This interpretation supports the transformation argument advanced by the CC. ${ }^{173}$ It seems that there is much stronger justification for an option 3-type approach to the relationship between the state and private actors in the mineral resource context as might first meet the eye: changing contexts have justified the varying the scope of private actors' powers and privileges over time; and in the current context of transformative constitutionalism it is this option 3-type approach that justifies even significant inroads on property, without creating the impression that for the sake of transformation proprietary positions relating to mineral resources are no longer secure.

171 See H Mostert, n 10 , 2, 24-25, 44, 53, 59.

172 See H Mostert, n 10, ch 3-5 and B Hepple, n 54, 760-770.

173 AgriSA CC [60] and [70]. 


\section{Conclusion}

Scope constraints do not allow anything more than a rather superficial reconsideration of the problematic concept of mineral rights. The above analysis, however, should have indicated that much of the difficulty that is experienced in interpreting parts of the MPRDA today has its roots in how the nature of the mineral right as a concept was theorised by the courts and scholarship for almost a century. The mistake, to my mind, was that the concept of mineral rights was theorised largely - perhaps even exclusively - in terms of private property law, with very little academic regard for the regulatory context in which the rights were allowed to be exercised.

Moreover, South African law was hesitant - for reasons I could not explore in any depth in this article - to acknowledge the mineral right as a form of ownership. Instead it considered the mineral right to be a ius in re aliena. ${ }^{174}$ This was an error of which the repercussions of which still reverberate in our law. Apart from the dogmatic inconsistencies it caused, and apart from the inability of the law to deal with these inconsistencies, categorising the concept as a right in respect of the property of another caused confusion about the consequences of severance, which was meant to lend mineral title, rather than servitudal rights to holders. In the MPRDA itself, the choice of terminology in section 5(1) perpetuates such misunderstandings. The provision refers to mining rights, prospecting rights and other rights in respect of minerals as "limited real rights". It does not make clear, however, that these rights are derived from the ownership of the mineral resource itself, rather than from the ownership of the land in which the minerals are situated.

Finally, in conceptualising the mineral right, not enough attention was paid to the very crucial element of how the right or title is curtailed by the state's regulatory ability as it is exercised in permitting prospecting and mining. Had this element been given due regard, it would probably have been much less controversial for the MPRDA to do what it set out to: ensure that both the access to our mineral resources and exploitation thereof are imbued with the values of equity, sustainability and fairness. 